\title{
A COMPARATIVE STUDY ON INDOOR RADON LEVELS BETWEEN THE LUNG CANCER AND CANCER FREE GROUPS IN IZMIR PROVINCE, TURKEY
}

\author{
Turkan Ozbay ${ }^{1}$, Ozlem Karadeniz², Ozgul Vupa Cilengiroglu ${ }^{3}$, Hatice \\ Durak $^{4}$, Sultan Eser ${ }^{5}$
}

\footnotetext{
${ }^{1}$ Izmir University of Economics, Vocational School of Health Services, Izmir, Turkey

2 Dokuz Eylul University, Faculty of Sciences, Department of Physics, Izmir, Turkey.

${ }^{3}$ Dokuz Eylul University, Faculty of Sciences, Department of Statistic, Izmir, Turkey.

${ }^{4}$ Dokuz Eylul University, Faculty of Medicine, Department of Nuclear Medicine, Izmir, Turkey.

${ }^{5}$ Hacettepe University, Ankara \& Izmir Cancer Registry, Izmir, Turkey
}

Address for Correspondence: Lect. Turkan Ozbay E-mail: turkan.ozbay@ieu.edu.tr Received: 21.02.2021; Accepted: 27.07.2021; Available Online Date: 20.09.2021

(C) Copyright 2021 by Dokuz Eylül University, Institute of Health Sciences - Available online at https://dergipark.org.tr/en/pub/jbachs

Cite this article as: Ozbay T, Karadeniz O, Vupa-Cilengiroglu O, Durak H, Eser S. A Comparative Study on Indoor Radon Levels between the Lung Cancer and Cancer Free Groups in Izmir Province, Turkey. J Basic Clin Health Sci 2021; 3: 1622.

\begin{abstract}
Purpose: Izmir is the province of Turkey with the highest lung cancer incidences for males, therefore a comparative study was performed in particular districts of Izmir in 2013. In the study, it was aimed to assess the association between lung cancer risk and indoor radon.

Methods: Patients diagnosed with lung cancer between 2010 and 2011 were selected from the database of the Izmir Cancer Registry (ICR). Measurements of indoor radon concentrations were performed in a total of 117 locations using the SSNTD (Solid State Nuclear Track Detectors) method with LR-115 detectors. Indoor radon concentration measured in homes of patients with lung cancer and cancer free group were compared statistically.

Results: The indoor Radon (222Rn) activity concentration detected ranged from 165 to $487 \mathrm{~Bq} / \mathrm{m3}$, for the lung cancer group, from 28 to $367 \mathrm{~Bq} / \mathrm{m} 3$ for the cancer free group, with geometric means of 269 $\mathrm{Bq} / \mathrm{m} 3$ and $123 \mathrm{~Bq} / \mathrm{m}^{3}$, respectively.

Conclusion: According to the logistic regression model, as radon concentration and package/year increased, the rate of cancer increased multiple folds. These results suggest that indoor radon levels may contribute to higher rates of lung cancer for Izmir compared to the rest of the country, and indoor radon levels may be a contributory factor in this phenomenon.
\end{abstract}

Keywords: Lung cancer, Izmir, indoor radon, passsive track detectors

\section{INTRODUCTION}

${ }^{222} \mathrm{Rn}$ (Radon) is formed by alpha decay of ${ }^{226} \mathrm{Ra}$ and ${ }^{230} \mathrm{Th}$, which are the decay products of ${ }^{238} \mathrm{U}$, and have half-lives of 1.600 and 75.380 years, respectively. Although the half-life is 3.82 days, radon, the only radioactive gas in the uranium series, is permanent in nature, and the heaviest member of the chemically inert gas family [1].

Because radon decay products are heavy charged particles, energy passing through the bronchus and cellular structure of the lung surface damages the cells, causing them to die. The body can tolerate and 
Table 1. Descriptive statistics and $p$ values for risk factors of case-control group (House, Age and Smoking)

\begin{tabular}{|c|c|c|c|c|c|}
\hline \multicolumn{3}{|c|}{ Case } & \multicolumn{2}{|l|}{ Control } & t test \\
\hline & $\left(\right.$ Mean \pm Std $\left.^{a}\right)$ & (Min-Max) & $\left(\right.$ Mean \pm Std $\left.^{a}\right)$ & (Min-Max) & p-value \\
\hline House $^{b}$ & $277.06 \pm 69.67$ & $165.0-487.0$ & $132.14 \pm 50.53$ & $27.5-366.5$ & $0.000<0.05$ \\
\hline Age & $62.46 \pm 8.51$ & $50.0-87.0$ & $60.70 \pm 10.62$ & $38.0-90.0$ & $0.000<0.05$ \\
\hline Smoking & $61.13 \pm 26.05$ & $2.5-110.0$ & $23.84 \pm 20.92$ & $2.5-70.0$ & $0.323>0.05$ \\
\hline
\end{tabular}

a Standard deviation, ${ }^{\mathrm{b}}$ Indoor radon of house

repair dying cells; however, the damaged lung tissue cells can proliferate, and cellular defects may eventually lead to lung cancer [2]. Recently, the inhalation of high concentrations of radon has emerged as a significant cause of increased risk of lung cancer [3, 4]. Radon is classified as a known human carcinogen by IARC (The International Agency for Research on Cancer), and the World Health Organization (WHO) reported that radon and its decay products were the most important cause of lung cancer after smoking [5].

Because of these health effects, numerous casecontrol studies on indoor radon and lung cancer risk have been conducted [6]. Some studies revealed a positive or weakly positive relationship between lung cancer risk and indoor radon concentrations, while others, an inconsistent relationship. Until recently, no case-control study has negative relationship [7]. Radon is estimated to cause between 3 and $14 \%$ of all lung cancers, depending on the average radon level in the country [5]. As mentioned in the previous study, smokers are predicted to be 25 times more at risk from radon than non-smokers. In addition, synergistic interactions between smoking and other factors, such as asbestos and radon were also estimated to contribute the risk of lung cancer [8].

Izmir Cancer Registry (ICR) collects data from various sources, particularly hospital cancer registration units. ICR historically reported much higher lung cancer age standardized incidence rates (ASR) in males than in females in Izmir [9-12]. The Male/Female ASR ratios was 13, 12 for the first series (1993-94, 1996-2000, 1998-2002) published [9] and diminished to 9.2, 9.0 for the following years (20032007) [10, 11]. Lung cancer ASRs in males have been the highest amongst all ASRs, while ASRs in females are similar to those reported by the population-based cancer registries in the other provinces of Turkey [10, 11]. Furthermore, in 20032007, Lung Cancer ASR in males was 90.1, the highest lung cancer ASR in the World, whilst it was only 10.0 in females [11].

This pattern of much higher ASRs in males than in females is compatible with the historical data on smoking prevalence in Turkey, which have been much higher in males [13] and a substantial amount of the incidence might have been elucidated with the smoking exposure. Eser et al. reported that $92.5 \%$ of all male cancers in Izmir, and $88.3 \%$ in Turkey were attributable to smoking [14].

Nevertheless, this much higher rate still need to be studied to determine whether there is any contribution to the lung cancer burden in Izmir from other possible environmental or occupational risk factors with synergistic effects with smoking for lung cancer. Namely, much radon data is available for different provinces of Turkey, and Izmir radon level higher than mean value for Turkey $\left(81 \mathrm{~Bq} / \mathrm{m}^{3}\right)$ [15-17].

Considering the importance of the subject, there is need for a comparative study examining the relationship between radon and lung cancer in Izmir, Turkey. Therefore, an extensive investigation was started in 2013, and in the present study, it was aimed to assess the association between indoor radon and lung cancer risk; to report the indoor radon concentrations in lung cancer cases, and to correlate them with three case characteristics (sex, age at diagnosis, and smoking), and to assess the importance of indoor radon as a risk factor for lung cancer and cancer free groups. In this sense, our study, which reveals potentially important results, is 
Table 2. Frequency tables for risk factors (Gender and District)

\begin{tabular}{|c|c|c|c|c|}
\hline & Case & & Control & \\
\hline & (Frequency) & (Percent, \%) & (Frequency) & (Percent, \%) \\
\hline \multicolumn{5}{|l|}{ Gender: } \\
\hline Female & 7 & 11.1 & 18 & 33.3 \\
\hline Male & 56 & 88.9 & 36 & 66.7 \\
\hline \multicolumn{5}{|l|}{ District: } \\
\hline Karşıyaka & 10 & 15.9 & 16 & 29.6 \\
\hline Bayraklı & 16 & 25.4 & 16 & 29.6 \\
\hline Bornova & 17 & 27.0 & 15 & 27.8 \\
\hline Buca & 20 & 31.7 & 7 & $\begin{array}{ll}13.0 \\
\end{array}$ \\
\hline
\end{tabular}

the first to explore the role of radon exposure in lung cancer development in Izmir.

\section{METHODS}

\section{Data Sources}

Izmir province with a population of 4.367 million (2019) is a metropolitan city in the western extremity of Anatolia, the third most populous in Turkey, after Istanbul and Ankara [18]. ICR is now functioning a department of the Izmir Provincial Public Health Directorate under the Ministry of Health. The registry follows the international standards for abstracting and coding the cases. It collects data from all health care facilities in the province [9].

\section{Constructing Groups}

The database of the ICR, which includes all cancer patients in Izmir was used. Individuals diagnosed with lung cancer with microscopical confirmation and recorded between 2010 and 2011 were selected for the study. Four districts with the highest population and patient density were chosen for the study: Karşıyaka, Bornova, Bayraklı and Buca districts in Izmir. The patients over 50 years old and living in the same house for at least five years were selected for the investigation.

In order to compare the indoor radon concentration in patients' homes with other homes, the study included participants without lung cancer. While constructing the cancer free group, individuals who lived in the same neighborhood, in similar buildings and on comparable storeys as the lung cancer patients were selected to control for environmental exposures, such as air pollution or arsenic exposure via drinking water. Individuals over 50 years of age in the selected houses were interviewed at home, and a survey was conducted. Efforts were made to match age and sex variables with the lung cancer patient group, however due to difficulties in recruiting participants in the near neighborhoods, a gender difference occurred between two groups.

117 locations were investigated, namely 26 in Karşıyaka (10 patients-16 healthy people); 27 in Buca (20 patients-7 healthy people); 32 in Bornova (17 patients-15 healthy people); 32 in Bayraklı (16 patients-16 healthy people). The numbers of smokers and non-smokers were 89 and 28 , simultaneously.

\section{Measurement of Radon Concentrations}

In the present study, long-term radon concentrations in the homes of patients diagnosed with lung cancer and others were measured by using LR 115-II passive track detectors (Dosirad, France). The radon measuring device consists of a plastic cup of $7 \mathrm{~cm}$ height, $7.2 \mathrm{~cm}$ diameter at one end, and $5 \mathrm{~cm}$ at the other, in which LR-115 detector with dimensions 1.2 $\mathrm{cm} \times 1.2 \mathrm{~cm}$ was fixed. The response of the track detectors placed into the cup-type measuring device was obviously determined [19]. A description of radon measurements for the measuring instruments is presented in another study [16]. Radon concentrations in indoor air $\left[\mathrm{C}_{\circ}\left(\mathrm{Bq} / \mathrm{m}^{3}\right)\right]$ using the $\mathrm{LR}$ 115-II was calculated by the following equation [20].

$$
C_{0}=D_{0} / k
$$

where $D_{\circ}\left(\operatorname{tr} \mathrm{cm}^{-2} \mathrm{~d}^{-1}\right)$ is the net detector track density of the radon alpha particles, and $\mathrm{k}\left(\mathrm{Bq}^{-1} \mathrm{~m}^{3} \mathrm{tr}_{\mathrm{cm}}^{-2} \mathrm{~d}^{-}\right.$ ${ }^{1}$ ) is the detector sensitivity coefficient, that is calibrated.

The net track density is the difference between the observed track density (determined by counting the 
Table 3. Spearman correlation coefficients and $p$ values for risk factors

\begin{tabular}{llllll}
\hline \hline & Gender & House & Smoking & Age & District \\
\hline Gender & 1 & $0.174(0.061)^{*}$ & $0.363(0.000)$ & $-0.008(0.929)$ & $0.162(0.082)$ \\
\hline \hline House $^{* *}$ & $0.174(0.061)$ & 1 & $0.538(0.000)$ & $0.209(0.024)$ & $0.273(0.003)$ \\
\hline \hline Smoking & $0.363(0.000)$ & $0.538(0.000)$ & 1 & $0.325(0.002)$ & $0.148(0.165)$ \\
\hline \hline Age & $-0.008(0.929)$ & $0.209(0.024)$ & $0.325(0.002)$ & 1 & $-0.103(0.270)$ \\
\hline \hline District & $0.162(0.082)$ & $0.273(0.03)$ & $0.148(0.270)$ & $0.270)$ & 1 \\
\hline " $p$ values are shown in parenthesis, ${ }^{* *}$ Indoor radon of house & & & & \\
\hline
\end{tabular}

number of tracks per unit area) and background found on unexposed material. The measured net track density is converted into radon concentrations $\left(\mathrm{Bq} / \mathrm{m}^{3}\right)$ using the calibration factor $\left(0.0386 \mathrm{~Bq}^{-1} \mathrm{~m}^{3} \mathrm{tr}\right.$ $\left.\mathrm{cm}^{-2} \mathrm{~d}^{-1}\right)$. To determine the calibration factor, a set of unexposed LR-115 detectors was installed for 1-5 d inside a 225-liter radon calibration chamber (equilibrium radon concentration: $3.24+0.04 \mathrm{kBq} / \mathrm{m}^{3}$ ) at the Health Physics Department of the Çekmece Nuclear Research and Training Centre, ÇNAEM, which participated in the National Radiological Protection Board (NRPB) of inter-comparisons (1989, 1991, 1995, 2000) [15]. The calibration chamber was calibrated by sampling with Lucas flasks.

Assuming the validity of Poisson statistics, the detection limit $L_{D}$ is defined by $L_{D}=2.71+3.29 \sigma_{B}$ based on the Currie criteria [21] in the case of a well-known background track density where $\sigma_{B}$ is the background standard deviation. The Minimum Detectable Concentration (MDC) for radon corresponds to $L_{D}$ expressed in activity concentrations unit by using the calibration factor. The corresponding MDC for radon by using the calibration factor is estimated $12 \mathrm{~Bq} / \mathrm{m}^{3}$ for two-month exposure. The precision of the detectors is improved by counting a relatively larger detector area (about $100 \mathrm{~mm}^{2}$ ).

In this work, measurements were recorded for an exposure period of approximately 2 months between February-April 2013. First of all, general information about our investigation was given to the participants. The radon dosimeters were set up in the rooms at a height of approximately $1.5 \mathrm{~m}$ from the floor and away from open windows, doors, radiators, fans, etc. because excessive air movement may affect the radon concentration. To increase the reliability, radon measuring devices were installed in bedrooms and living rooms in each home. All investigated buildings were constructed from reinforced concrete, fired clay bricks and cement.
The radon dosimeters were retrieved at the end of the exposure period. The passive detectors were etched in $10 \% \mathrm{NaOH}$ solution at $60{ }^{\circ} \mathrm{C}$ for $95 \mathrm{~min}$ in a constant temperature etching unit (accuracy: $\pm 1^{\circ} \mathrm{C}$ ). After the etching, detectors were then washed with distilled water and dried. The alpha tracks were counted using a binocular research microscope at a magnification of $10 \times 10$. Background track density of the unexposed detector was separately counted and subtracted from the observed values.

\section{Questionnaire}

The questionnaire included the questions related to the other risk factors, and detailed questions on exposure to tobacco smoking was conducted with both the lung cancer and cancer free groups.

\section{Statistical Analyses}

First, the descriptive statistics were performed for the continuous risk factors, and used to compare the lung cancer group with the cancer free group, and the frequency tables were prepared for the discrete ones. Later, the differences between the groups averages for the "house", "smoking", and "age" variables were examined using two samples t-test. The relations between the risk factors were examined using the correlation coefficient and the logistic regression model was constructed for those factors thought to be influential in causing cancer. Statistical analyses were performed using SPSS (13.0).

\section{RESULTS}

In this study, for the lung cancer group, the indoor ${ }^{222} \mathrm{Rn}$ activity concentration detected ranged from 165 to $487 \mathrm{~Bq} / \mathrm{m}^{3}$, and for the cancer free group, from 28 to $367 \mathrm{~Bq} / \mathrm{m}^{3}$, with geometric means of $269 \mathrm{~Bq} / \mathrm{m}^{3}$ and $123 \mathrm{~Bq} / \mathrm{m}^{3}$, respectively (Table 1 ).

The two groups were the lung cancer group, comprised of patients diagnosed with lung cancer $(n=63)$, and a cancer free group $(n=54)$. The risk 
Table 4. Logistic regression model for house and smoking variables

\begin{tabular}{lllllll}
\hline Variables & Beta & S.E. $^{\mathbf{a}}$ & Wald & p-value $^{\mathbf{b}}$ & OR $^{\mathbf{c}}$ & $\mathbf{9 5 \%}^{\text {CI for OR }}$ \\
\hline \hline House & 0.132 & 0.056 & 5.505 & 0.019 & 1.141 & $1.022-1.275$ \\
\hline \hline Smoking & 0.103 & 0.050 & 4.235 & 0.040 & 1.109 & $1.005-1.223$ \\
\hline \hline Constant & -28.797 & 12.098 & 5.666 & 0.017 & 0.000 & \\
\hline \hline
\end{tabular}

a Standard Error, ${ }^{b}$ p-value $<0.05$ is significant, ${ }^{c}$ Odds ratio, d $95 \%$ Confidence Interval for Odds Ratio

factors thought to be influential in lung cancer were indoor radon concentration (house), package/year (smoking), district and age variables. These factors were recorded for the two groups. The values of radon concentration of bedroom and living room were also measured. However, the relation between these variables was found statistically significant according to Pearson correlation coefficient $(r=0.887, p=0.000)$. Therefore, it was decided to use the house average concentration instead of these two variables. First, the descriptive statistics for these risk factors are presented in Table 1. It is observed that the in indoor radon concentration in the lung cancer group was higher than the cancer free group. The age variable was homogenous in both groups. The smoking variable, on the other hand, was higher in the lung cancer group than the cancer free group. When the differences between the averages of the two groups are examined, a statistically significant difference was found between the $p$ values pertaining the two samples t-test results for the indoor radon concentration and package/year variables with a $99 \%$ confidence interval, but not for the age variable (Table 1). As it can be seen from the frequency table, the percentage of males in the lung cancer group was higher than the cancer free group. When the results are examined with reference to the districts, the lung cancer group was smallest in Karşıyaka and largest in Buca (Table 2). According to the Spearman correlation coefficient, a statistically significant difference was found between smoking, and gender, radon and age; and between radon, and age and district with a $95 \%$ confidence $(p<0.05)$ (Table 3$)$.

In the logistic regression model, which was constructed with the risk factors thought to have influence the development of cancer, the backward elimination method was used from among the variable selection methods. The significance level was taken as 0.05 . As a result of backward elimination, the indoor radon concentration and package/year variables remained in the logistic regression model. The $p$ values for the Wald test statistics of these variables were smaller than 0.05 and were found statistically significant with a $95 \%$ confidence $(0.019$ and $0.040<0.05)$. The Odds Ratio (OR) values, which indicate the risk rates for developing cancer, were found for radon concentration and package/year variable as 1.141 and 1.109 respectively, and since the confidence intervals did not include the value 1 , they were found significant (Table 4). This indicates that as radon concentration and package/year increased, the rate of cancer increased in multiple folds. Finally, the logistic regression model was established in nonsmokers. As a result of analysis, the indoor radon concentration (house variable) was found as statistically significant (Table 5) also.

\section{DISCUSSION}

Although persistent high lung cancer ASRs are compatible with the historically high smoking prevalence among Izmir males, exposure to environmental and/or occupational risk factors might also play a role. A comparative study was performed in particular districts of Izmir, which has the highest lung cancer incidences in Turkey. A statistically comparison was made of indoor radon concentration recorded in homes of the lung cancer and the cancer free group. We found statistically significant elevated ORs for high radon concentrations both in smokers $\left(\mathrm{OR}=1.141 \mathrm{per} \mathrm{Bq} / \mathrm{m}^{3}\right.$ ) and nonsmokers $(\mathrm{OR}=1.023$ per $100 \mathrm{~Bq} / \mathrm{m}^{3}$ ) for those exposed high radon concentrations, consistent with many previous studies on indoor radon and lung cancer risk. In a systematic review, a relative risk of $1.44(95 \% \mathrm{Cl} 1.0-$ 2.1) was reported for those exposed to concentrations higher than $140 \mathrm{~Bq} / \mathrm{m}^{3}$ compared with these exposed to lower than $50 \mathrm{~Bq} / \mathrm{m}^{3}$ concentrations [22].

According to the logistic regression model, as radon concentration and package/year increased, the cancer rate increased in multiple folds. These results suggest that indoor radon levels may contribute to higher lung cancer rates for Izmir compared to the rest of the country, and that indoor radon levels may 
Table 5. Logistic regression model for house variable in nonsmoker group

\begin{tabular}{|c|c|c|c|c|c|c|}
\hline Variables & Beta & S.E. ${ }^{a}$ & Wald & p-value ${ }^{b}$ & $\mathbf{O R}^{\mathrm{c}}$ & $95 \%$ CI for $\mathrm{OR}^{\mathrm{d}}$ \\
\hline House & 0.023 & 0.010 & 4.874 & 0.027 & 1.023 & 1.003-1.044 \\
\hline בConstant & -5.962 & 2.164 & 7.591 & 0.006 & 0.003 & \\
\hline
\end{tabular}

${ }^{a}$ Standard Error, ${ }^{b}$ p-value $<0.05$ is significant, ${ }^{c}$ Odds ratio, ${ }^{d}$ 95\% Confidence Interval for Odds Ratio

be a contributory factor in many lung cancer cases in Izmir. Therefore, radon concentration should be kept as low as possible

To our knowledge, this is the first known study related to relationship between lung cancer and indoor radon for small geographical areas in Turkey. Guidelines to reduce radon entry into buildings have been introduced by TAEK (Turkish Atomic Energy Authority), but further studies should be encouraged.

To conclude, the exposure to indoor radon might increase the risk of lung cancer for smokers and nonsmokers alike. However, further research is needed and carefully-designed case-control studies should be conducted in order to reveal the exact magnitude of this risk. Nevertheless, our study provides an evidence-based support not only for the radon control activities, but for the ongoing tobacco control programs in the country.

Acknowledgement: The authors would like to thank Nilsu Çini for her help in setting up the detectors and collecting them back. The authors are also grateful to Prof. Dr. Ayşe Nur Demiral for her encouragement and Dr. Cankut Yakut for his help in the construction of lung cancer group.

Ethical approval: It was approved by the non-interventional research ethics committee of Dokuz Eylül University with the date of 21.03.2013, 939-GOA protocol number and decision number 2013/10-19.

Funding: This work was supported by Dokuz Eylül University Scientific Research Project [Grant number 2013.KB.SAG.035] Conflict of Interest: The authors report no conflict of interest. Peer-review: Externally peer-reviewed.

\section{REFERENCES}

1. Sykora I, Froehlich K. Radionuclides as tracers of atmospheric process. In: Froehlich $\mathrm{K}$, editor. Environmental Radionuclides: Tracers and Timers of Terrestrial Processes, Oxford, Elsevier; 2010. pp. 51-88.

2. Martin JE. Physics for Radiation Protection. 2nd ed. Weinheim, WILEY-VCH. 2006. 288-289.

3. Harley $\mathrm{NH}$, Harley $\mathrm{JH}$. Potential lung cancer risk from indoor radon exporsure. Cancer J Clin_1990; 40(5): 265-275.
4. International Commission on Radiological Protection (ICRP). ICRP Publication 65: Protection Against Radon-222 at Home and at Work. Ann. 1993; 23(2).

5. Zeeb H, Shannoun F. WHO Handbook on Indoor Radon: a Public Health Perspective. Geneva, Switzerland, World Health Organization 2009.

6. Darby S, Hill D, Auvinen A, et al. Radon in homes and risk of lung cancer: collaborative analysis of individual data from 13 European case-control studies. BJM 2005; 330: 223.

7. Krewski D, Lubin JH, Zielinski JM, et al. Residential radon and risk of lung cancer, a combined analysis of 7 North American casecontrol studies. Epidemiology 2005; 16(2): 137145.

8. Alberg AJ, Brock MV, Ford JG, Samet JM, Spivack SD. Epidemiology of lung cancer: Diagnosis and management of lung cancer, 3rd ed: American college of chest physicians evidence-based clinical practice guidelines. Chest 2013; 143(5 Suppl): 1-29.

9. Fidaner C, Eser SY, Parkin DM. Incidence in Izmir in 1993-1994: first results from Izmir Cancer Registry. Eu J Cancer 2001; 37(1): 83-92.

10. Eser S, Yakut C, Özdemir R, et al. Cancer incidence rates in Turkey in 2006: A detailed registry based estimation. Asian Pac J Cancer Prev 2010; 11(6): 1731-1739.

11. Cancer Incidence in Five Continents, Vol. $X$ (electronic version). Lyon: International Agency for Research on Cancer. Available from: http://ci5.iarc.fr/Default.aspx (accessed 27 January 2021). The printed version of this volume (IARC Scientific Publication No. 164).

12. Eser S. Life time cumulative risks for cancers in Turkey. Tur J Public Health 2015; 13(2): 87-96. http://tjph.org/ojs/index.php/TJPH/article/view/1

13. Turkish Statistical Institute (TÜIK), Family Structure Research 2006. (accessed 27 January 2021). http://www.turkstat.gov.tr/Kitap.do?metod=Kitap Detay\&KT_ID=11\&KITAP_ID=16 
14. Eser S, Pisani P. Tobacco related cancers in Turkey and Izmir. 28th Annual Meeting of the International Association of Cancer Registries, Cancer and Environment (IACR); 2006 Oct 7-10; Goiania-Goias, Brasil. http://www.iacr.com.fr/index.php?option=com_c ontent\&view $=$ article $\&$ id $=112 \&$ Itemid $=581$

15. Celebi N, Ataksor B, Taskın H, Albayrak Bingoldag N. Indoor radon measurements in Turkey dwellings. Radiat Prot Dosim 2015; 167(4): 626-632.

16. Alkan T, Karadeniz Ö. Indoor ${ }^{222} \mathrm{Rn}$ levels and effective dose estimation of academic staff in İzmir-Turkey. Biomed Environ SCI 2014; 27(4): 259-267.

17. Karadeniz Ö, Yaprak G, Akal C, Emen, I. Indoor radon measurements in the granodiorite area of Bergama (Pergamon)-Kozak, Turkey. Radiat Prot Dosim 2012; 149(2): 147-154.

18. Turkish Statistical Institute (TÜIK): https://data.tuik.gov.tr/Bulten/Index?p=TheResults-of-Address-Based-PopulationRegistration-System-2019-33705\&dil=2 (accessed 25 August 2020).

19. Somogyi G, Paripas B, Varga Zs. Measurement of radon, radon daughters and thoron concentrations by multi-detector devices. Nucl Tracks Rad Meas 1984; 8(1-4): 423-427.

20. Planinic J. ${ }^{222} \mathrm{Rn}$ detection efficiency and sensitivity coefficient of the LR 115-II nuclear track detector. Health Phys1992; 62(4): 356-358.

21. Currie LA. Limits for qualitative detection and quantitative determination. Application to radiochemistry. Anal Chem 1968; 40(3): 586-593.

22. Torres-Durán M, Barros-Dios JM, FernándezVillar A, Ruano-Ravina A. Residential radon and lung cancer in never smokers. A systematic review. Cancer Lett 2014; 345(1): 21-26. 